\title{
Echinostoma macrorchis Metacercariae in Cipangopaludina chinensis malleata from Xiengkhuang Province, Lao PDR and Morphologies of Adults from Experimental Animals
}

\author{
Woon-Mok Sohn ${ }^{1 *}$, Byoung-Kuk Na', Dongmin Lee ${ }^{2}$, Keeseon S. Eom², Tai-Soon Yong ${ }^{3}$, Jong-Yil Chai ${ }^{4,5}$, \\ Duk-Young Min $^{6}$ \\ ${ }^{1}$ Department of Parasitology and Tropical Medicine, and Institute of Health Sciences, Gyeongsang National University College of Medicine, Jinju \\ 52727, Korea; ${ }^{2}$ Department of Parasitology and Parasite Research Center, Parasite Resource Bank, Chungbuk National University School of \\ Medicine, Cheongju 28644, Korea; ${ }^{3}$ Department of Environmental Medical Biology and Institute of Tropical Medicine and Arthropods of Medical \\ Importance Resource Bank, Yonsei University College of Medicine, Seoul 03722, Korea; ${ }^{4}$ Institute of Parasitic Diseases, Korea Association of \\ Health Promotion, Seoul 07649, Korea; ${ }^{5}$ Department of Parasitology and Tropical Medicine, Seoul National University College of Medicine, \\ Seoul 03080, Korea; ${ }^{6}$ Department of Microbiology, Ulij University College of Medicine, Daejeon 34824, Korea
}

\begin{abstract}
We identified the echinostome metacercariae in Chinese mystery snails, Cipangopaludina chinensis malleata, from Xiengkhuang Province, Lao PDR with morphologies of adult worms recovered. Total 20 snails were examined with artificial digestion method and then the collected metacercariae were orally infected to a mouse and a rat. Adult worms recovered from experimental animals were observed with a light microscope and a SEM. The metacercariae were round, $125 \times 123 \mu \mathrm{m}$ in average size, with a moderately thick cyst wall, collar spines distributed in the head collar and excretory granules in 2 canals of excretory tube. Adult flukes (3-week-old in a rat) were elongated, ventrally curved and $5.310 \times 1.023 \mathrm{~mm}$ in average size. Head collar distinct, bearing 43 collar spines with 5 end group ones on each side. Oral sucker subterminal, prepharynx very short, pharynx well developed, and esophagus relatively short. Cirrus sac well developed, with a saccular seminal vesicle, and ventral sucker very large. Ovary round and on the median line of the body. Testes tandom and elongated. Eggs operculated, elliptical and $90 \times 57 \mu \mathrm{m}$ in average size. In the SEM observation, the head crown prominent, with 43 collar spines resembled with horns of younger stag. Scale-like tegumental spines were densely distributed on the surface between the head collar and ventral sucker, and their densities were decreased posteriorly. Conclusively, the metacercariae detected in C. chinensis malleata from Lao PDR were identified as those of Echinostoma macrorchis based on the morphological characteristics of adult worms.
\end{abstract}

Key words: Echinostoma macrorchis, Cipangopaludina chinensis malleata, metacercaria, adult, Xiengkhuang Province, Lao PDR, Chinese mystery snails

\section{INTRODUCTION}

Trematode members in the family Echinostomatidae are intestinal parasites and can cause severe epigastric or abdominal pain, diarrhea, malnutrition and fatigue in humans and animals [1]. Total 8 genera, i.e., Echinostoma, Echinochasmus, Acanthoparyphium, Artyfechinostomum, Episthmium, Himasthla, Hypoderaeum and Isthmiophora, in this fluke group are known to be infected

\footnotetext{
- Received 22 August 2019, revised 11 October 2019, accepted 9 November 2019.

*Corresponding author (wmsohn@gnu.ac.kr)

(C) 2019, Korean Society for Parasitology and Tropical Medicine

This is an Open Access article distributed under the terms of the Creative Commons

Attribution Non-Commercial License (http://creativecommons.org/licenses/by-nc/4.0) which permits unrestricted non-commercial use, distribution, and reproduction in any

medium, provided the original work is properly cited.
}

humans worldwide. Among these, Echinostoma is the largest group as the type genus, consists of more than 60 species and about 6 ones, i.e., E. angustitestis, E. cinetorchis, E. echinatum, E. ilocanum, E. macrorchis, and E. revolutum are reported as the human infecting species $[1,2]$. Echinostoma macrorchis was originally described from naturally infected house rats, Rattus rattus and $R$. norvegicus, in Japan [3]. And then, this echinostomes have been detected in other rodent species, birds and even humans in Japan [4-8]. The presence of this fluke species was also confirmed in Taiwan, Lao PDR and the Republic of Korea (Korea) [9-13].

In Lao PDR, a species of the liver fluke, Opisthorchis viverrini, and several species of intestinal flukes, i.e., Haplorchis taichui, H. pumilio, H. yokogawai, Centrocestus formosanus, Prosthodendrium molenkampi, and Phaneropsolus bonnei, have been prevalently 
detected among riparian peoples in the several localities of Mekong basin [14-18]. And then human infections with 4 echinostome species, i.e., Echinostoma revolutum, Artyfechinostomum malayanum, Echinochasmus caninus, and Euparyphium sp. were also reported in riparian peoples of Khammouane Province $[19,20]$. Recently Sohn et al. [12] found E. macrorchis metacercariae in freshwater snails, Cipangopaludina sp., purchased from a local market in Vientiane Municipality and described the morphological characteristics of adult flukes obtained after experimental infection to rats and a cat. On the other hand, in the Korea-Lao PDR Collaborative Project for Control of Foodborne Trematode Infections (esp. Opisthorchiasis) in Lao PDR, we also focused the source of human infections to expand the trematode fauna in Lao PDR. Therefore, we intended to identify larval and adult echinostomes, which were originated from Chinese mystery snails, Cipangopaludina chinensis malleata, in Xiengkhuang Province, Lao PDR. And we described here some morphological and biological differences from the findings of previous studies, especially Sohn et al. [12].

\section{MATERIALS AND METHODS}

We collected Chinese mystery snails, C. chinensis malleata, (Fig. 1) in a field of Phonsavan in Xiengkhuang Province, Lao PDR in June 2011. Collected snails were transferred in our laboratory (Department of Parasitology and Tropical Medicine, Gyeongsang National University College of Medicine) with ice, and each 20 snails were digested with pepsin-HCl solution for $2 \mathrm{hr}$ after crushing their shells with a mortar. Metacercariae were collected in the digested materials under the stereomicroscope. Collected metacercariae were morphologically observed and measured under a light microscope with a micrometer. A mouse (ICR) and a rat (Sprague-Dawly) were infected orally with 100 metacercariae each. Adult worms were recovered in the small intestines of mouse and rat at 2 and 3 weeks after infection. In the animal experiments, the guidelines of animal experiments from Gyeongsang National University College of Medicine were followed. Each 10 adults recovered from a mouse and a rat were fixed with 10\% neutral buffered formalin under the cover glass pressure, stained with Semichon's acetocarmine, and observed their morphological characteristics and differential indices under a light microscope with a micrometer. To observe the surface ultrastructure, some of them were washed several times with 0.2 $\mathrm{M}$ cacodylate buffer (pH 7.2) and fixed with 2.5\% glutaraldehyde at $4^{\circ} \mathrm{C}$. After washing 3 times with the same buffer, they were dehydrated through a graded alcohol series $(50 \%, 70 \%$, $80 \%, 90 \%, 95 \%$ and absolute alcohol), dried with hexamethyldisilazane, coated (JFC-1100E ion sputtering device) with gold, and observed with a scanning electron microscope (Philips XL$30 \mathrm{~S})$ at $15 \mathrm{kV}$ accelerating voltage.

We basically measured the body length (BL) and width (BW), the size of oral sucker (OS) and ventral sucker (VS), pharynx, esophagus, head collar, cirrus sac, ovary and 2 testes, and additionally the forebody length (FBL: from the anterior
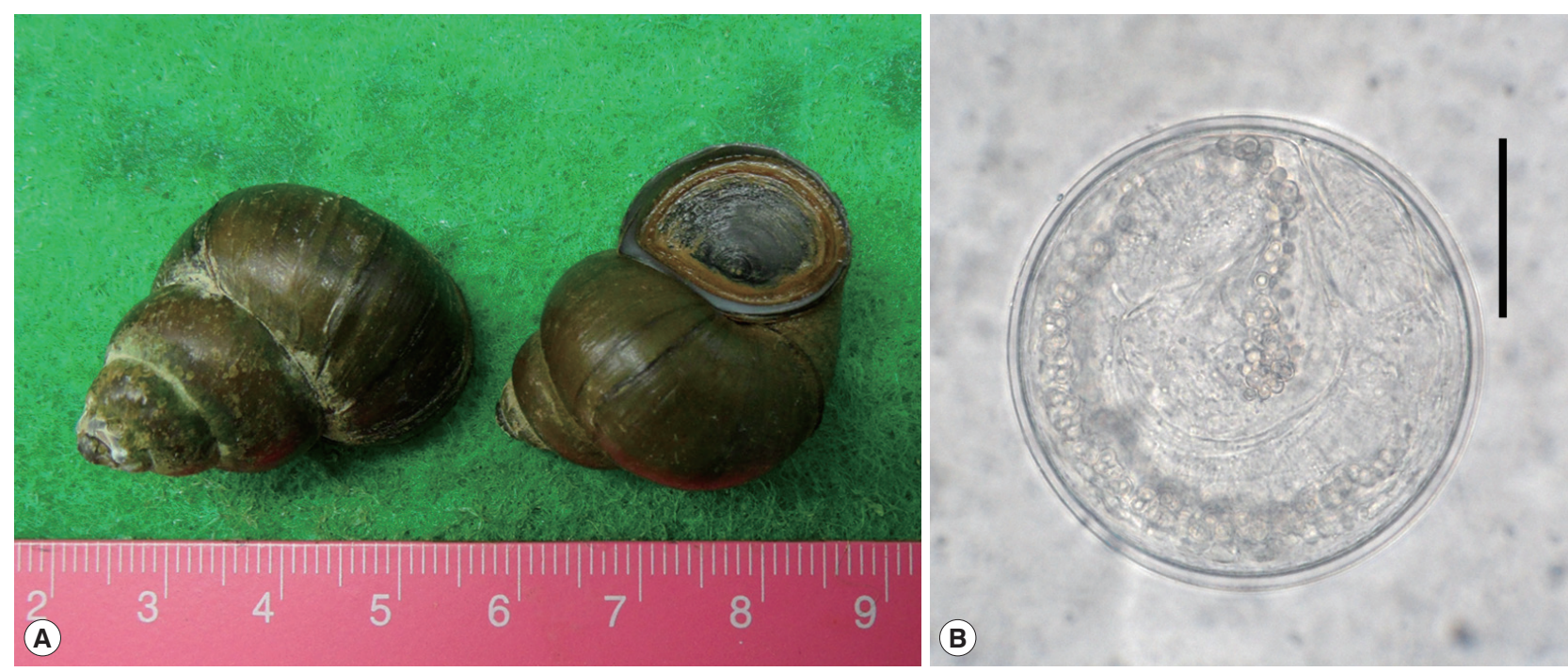

Fig. 1. (A) Two Chinese mystery snails, Cipangopaludina chinensis malleata, the second intermediate host of E. macrorchis, collected from a field of Xiengkhuang Province, Lao PDR. (B) A metacercaria of $E$. macrorchis detected in a Chinese mystery snail. Scale bar is $50 \mu m$. 
end to the anterior margin of the ventral sucker), hindbody length (HBL: from the posterior margin of the posterior testis to the posterior end) and uterus length (UL: from the posterior margin of the ventral sucker to the anterior margin of the ovary). And then we also calculated the ratio of BL/BW, VS/OS, the length/width in ovary and 2 testes, and percentage (\%) of $\mathrm{FBL} / \mathrm{BL}, \mathrm{HBL} / \mathrm{BL}$, and $\mathrm{UL} / \mathrm{BL}$ as the differential indices of this fluke. Measurements and scales are in micrometres $(\mu \mathrm{m})$.

\section{RESULTS}

\section{Infection status with E. macrorchis metacercariae in C. chinensis malleata}

The metacercariae of E. macrorchis were detected in 16 (80.0\%) out of 20 snails examined, and their densities were 1-72 (18 in average) per snail infected.

\section{Morphology of metacercariae (Fig. 2)}

The metacercariae $(\mathrm{n}=20)$ were round, $115-133(125) \times 113$ 133 (123) in size, with a moderately thick cyst wall, collar spines distributed in the head collar and excretory granules in two descending canals of the main excretory tube.

\section{Morphological characteristics of adult worms (3-week- old) (Fig. 3)}

Adult worms were elongated, ventrally curved, 4,975-6,000 long and 925-1,100 wide. Head collar distinct, 300-360 in width, bearing 43 collar spines with 5 end group ones on each
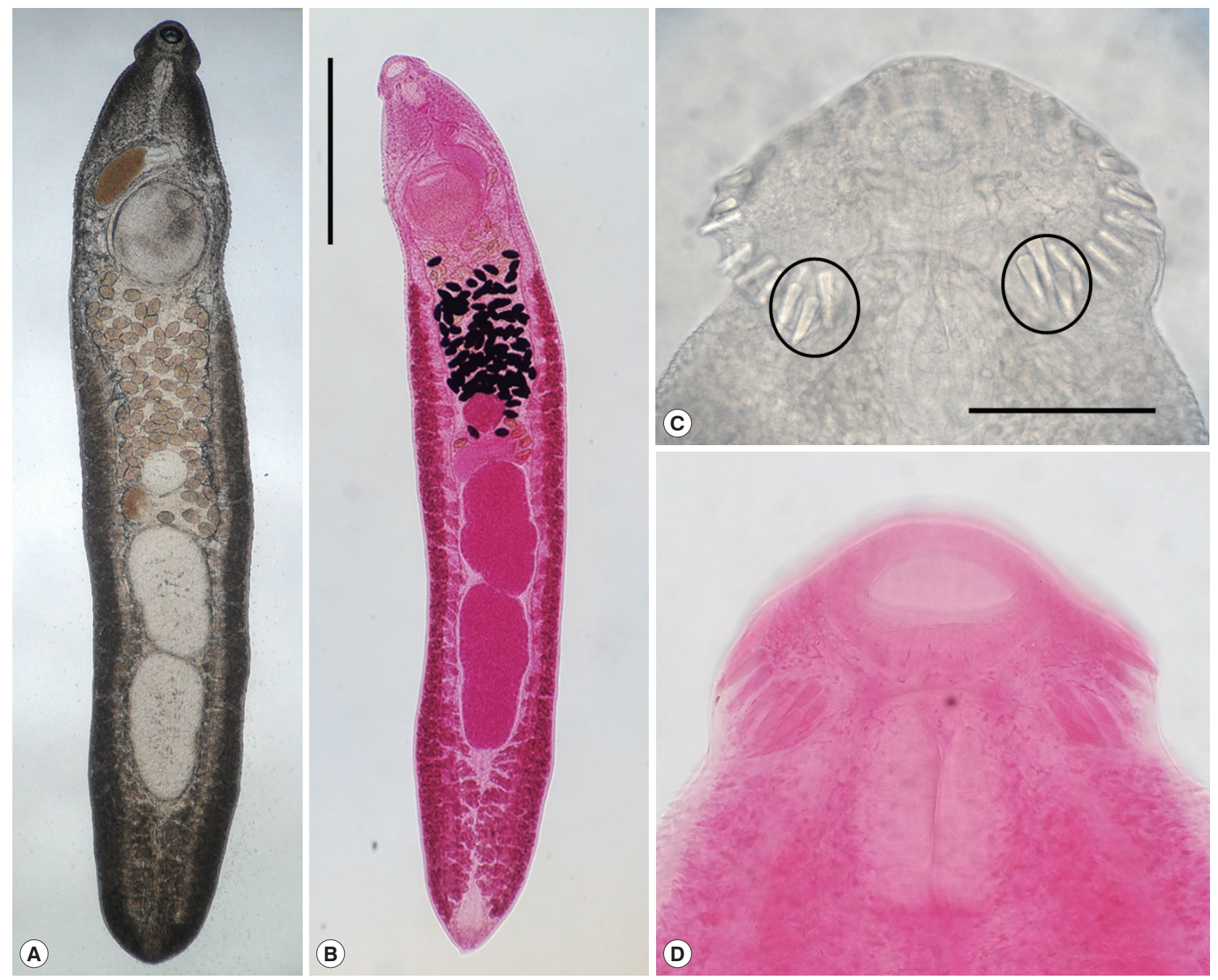

Fig. 2. Adult worms (3-week-old) of E. macrorchis (A: unstained; B: Semichon's acetocarmine stained) recovered from an experimental rat. Scale bar is 1,000 $\mu \mathrm{m}$. Head collar with 43 collar spines including 5 end group ones (encircle) on each side (C \& D). Scale bar is $100 \mu \mathrm{m}$. 

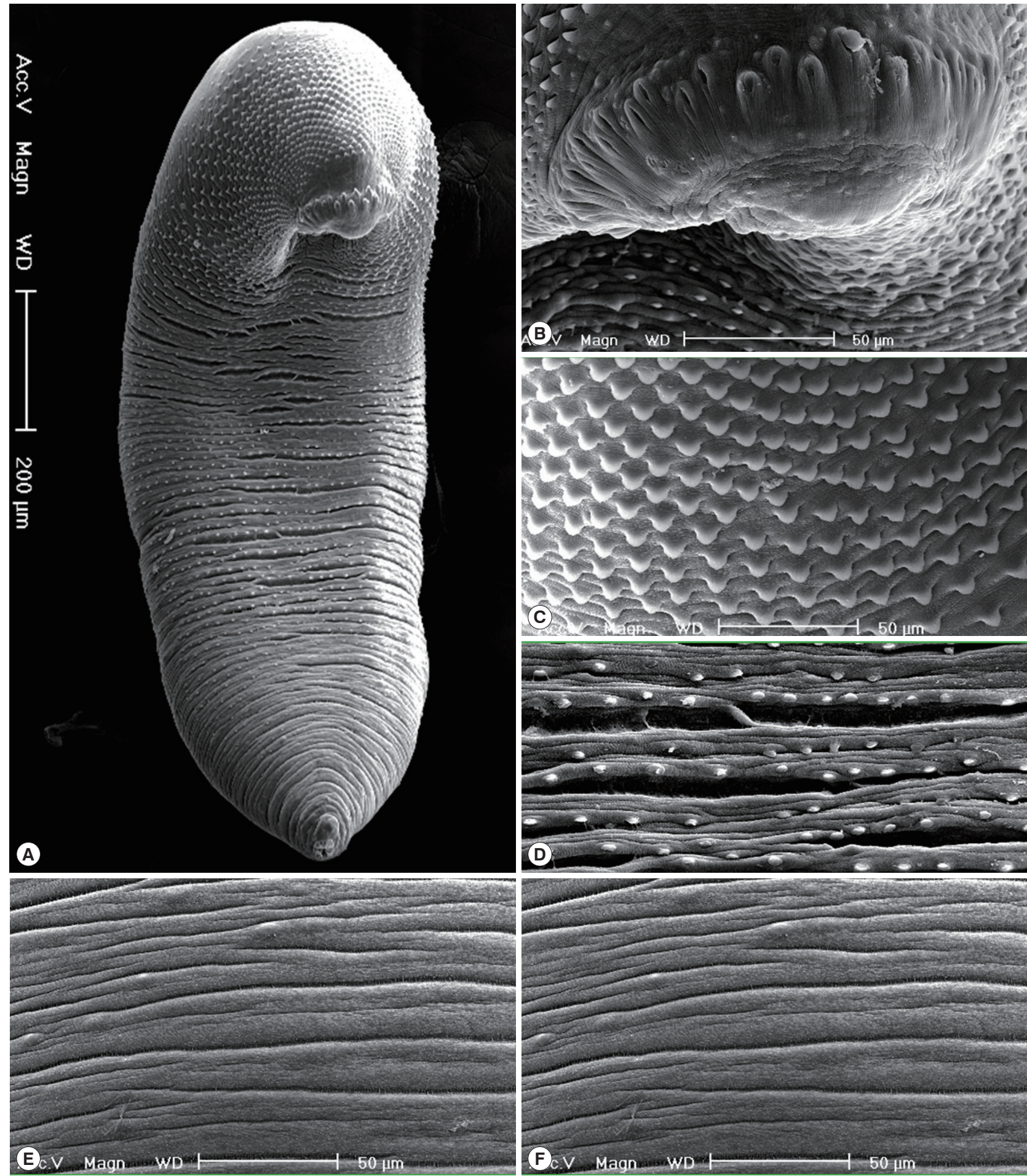

Fig. 3. Scanning electron microscopic (SEM) view of E. macrorchis adults (3-week-old) from an experimental rat. (A) Whole ventral view, which was elongated, ventrally curved and had the largest width near the middle portion of the body. (B) Dorsal view of the head collar showed 2 alternating rows of collar spines. (C) Scale-like tegumental spines were densely distributed on the body surface between the head collar and ventral sucker level. (D) Density of tegumental spines was decreased posteriorly on the tegumental surface from the behind of ventral sucker to the posterior $1 / 4$ level. (E, F) Tegumental spines were very rarely observed on the dorsal surface behind the ventral sucker level and ventral surface in the posterior portion. 
side. Oral sucker subterminal, $120-158 \times 145-178$ in size. Prepharynx very short. Pharynx well developed, $145-163 \times 98-125$ in size. Esophagus relatively short, 105-155 long. Cirrus sac well developed, with a saccular seminal vesicle, $230-350 \times 90$ 200 in size. Ventral sucker very large, 410-480 $\times 455-510$ in size. Ovary round, $225-325 \times 225-350$ in size, and on the median line of the body. Testes tandom, elongated, slightly indented, 650-820 ×360-500 (anterior testis) and 740-950 ×370-470 (posterior testis). Vitelline follicles bilaterally distributed from the anterior $1 / 4$ level of uterine field to the posterior end. Nu- merous eggs contained in the uterus located between the posterior margin of ventral sucker and ovary. Eggs operculated, elliptical and 88-96 (90) ×55-60 (57) in size. Dimensions of $E$. macrorchis from a mouse and a rat at 2 and 3 weeks after infection were detailedly revealed and compared with those of previous studies in Table 1.

In the SEM observation, adult worms were elongated, ventrally curved and had the largest width near the middle portion of the body (Fig. 3A). The head collar was well-developed and prominent bearing total 43 collar spines. A dorsal view of

Table 1. Dimensions ${ }^{a}$ of Echinostoma macrorchis adults recovered from mouse and rat experimentally infected with metacercariae from Chinese mistery snails from Xiengkhuang Province in Lao PDR and comparison with those of previous studies

\begin{tabular}{|c|c|c|c|c|c|}
\hline Organs & Present study (2019) & Present study (2019) & Lo $(1995)^{d}$ & Sohn et al. (2013) & Sohn et al. $(2017)^{f}$ \\
\hline Body (L) & $3,250-4,275(3,670)$ & $4,975-6,000(5,310)$ & $3,650-5,050$ & $3,900-4,730$ & $3,950-6,000(5,167)$ \\
\hline (W) & $600-800(713)$ & $925-1,100(1,023)$ & 680-900 & $730-880$ & $700-1,175$ (939) \\
\hline Oral sucker (L) & $103-130(115)$ & $120-158$ (135) & $100-170$ & $100-160$ & $105-150$ (123) \\
\hline (W) & $118-158$ (138) & $145-178(164)$ & in diameter & in diameter & $150-185(167)$ \\
\hline Head crown (W) & $253-300(278)$ & $300-360$ (334) & N.D. & $280-320$ & $300-375$ (334) \\
\hline Pharynx (L) & $108-138$ (121) & $145-163$ (153) & $120-150$ & $100-150$ & $130-165$ (150) \\
\hline$(W)$ & 78-108 (95) & $98-125$ (111) & in diameter & in diameter & $95-130(115)$ \\
\hline Esophagus (L) & 88-183 (142) & $105-155(134)$ & $120-210$ & $100-170$ & $95-175(135)$ \\
\hline Ventral sucker (L) & $350-435$ (391) & $410-480(456)$ & $400-490$ & $390-470$ & $395-490(441)$ \\
\hline (W) & $385-430$ (403) & $455-510(479)$ & in diameter & in diameter & $405-490(447)$ \\
\hline Cirrus sac (L) & $175-375(253)$ & $230-350(275)$ & $360-500$ & $250-370$ & $220-550(410)$ \\
\hline$(\mathrm{W})$ & $90-160$ (113) & $90-200$ (142) & N.D. & N.D. & 85-225 (163) \\
\hline Ovary (L) & $150-200(175)$ & $225-325$ (273) & $170-350$ & $170-260$ & $150-290(227)$ \\
\hline (W) & $150-225$ (184) & $225-350$ (278) & in diameter & in diameter & $160-335$ (250) \\
\hline Anterior testis (L) & $425-650$ (499) & $650-820(736)$ & $440-750$ & $500-700$ & $460-990$ (701) \\
\hline$(W)$ & $225-375$ (314) & $360-500(437)$ & $250-450$ & $330-450$ & 270-630 (427) \\
\hline Posterior testis (L) & $400-750(556)$ & $740-950$ (852) & $400-850$ & $540-830$ & $550-1,080(821)$ \\
\hline$(\mathrm{W})$ & $225-340$ (301) & $370-470(418)$ & $240-440$ & $330-420$ & $280-550$ (401) \\
\hline
\end{tabular}

${ }^{a}(L)$ : length; $(M)$ : width; unit is $\mu \mathrm{m}$. Each 10 worms recovered from a mouse and rat at ${ }^{\mathrm{b}} 2$ and ${ }^{\mathrm{c}} 3$ weeks after infection were measured.

'Total 20 worms from a rat in Taiwan.

${ }^{\mathrm{e} A}$ total of 10 worms recovered from a rat at 2 week after infection.

'Total 40 worms from exp. rats in Korea.

Table 2. Differential indices of Echinostoma macrorchis adults recovered from mouse and rat experimentally infected with metacercariae from Chinese mistery snails of Xiengkhuang Province, Lao PDR

\begin{tabular}{|c|c|c|c|}
\hline \multirow{2}{*}{ Organs } & \multicolumn{2}{|c|}{ Present study (2019) } & \multirow{2}{*}{ Sohn et al. (Average) } \\
\hline & 2-week-old in a mouse & 3-week-old in a rat & \\
\hline Body (L)/M) & 5.15 & 5.19 & $5.30-5.76(5.56)$ \\
\hline Vental sucker/Oral sucker & 3.13 & 3.12 & 3.03-3.18 (3.10) \\
\hline Ovary (L)/(W) & 0.95 & 0.98 & 0.93-0.97 (0.95) \\
\hline Anterior testis $(\mathrm{L}) /(\mathrm{W})$ & 1.59 & 1.68 & $1.57-1.89(1.71)$ \\
\hline Posterior testis(L)/(W) & 1.85 & 2.04 & $1.88-2.11(1.99)$ \\
\hline $\mathrm{FBL} / \mathrm{BL}^{\mathrm{a}} \times 100(\%)$ & 14.8 & 12.4 & 11.3-13.4 (12.5) \\
\hline $\mathrm{HBL} / \mathrm{BL}^{\mathrm{b}} \times 100$ & 18.7 & 18.2 & $18.9-21.9(20.6)$ \\
\hline UL/BL ${ }^{c} \times 100$ & 18.1 & 20.9 & 25.4-31.5 (28.2) \\
\hline
\end{tabular}

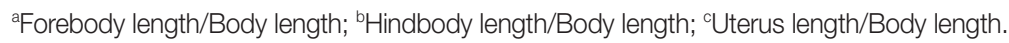


the head collar showed 2 alternating rows of collar spines (Fig. 3B). Scale-like tegumental spines were densely distributed on the body surface between the head collar and ventral sucker level (Fig. 3C), and their densities decreased posteriorly on the ventral surface (Fig. 3D). However, tegumental spines were very rarely observed on the dorsal surface behind the ventral sucker level and ventral surface in the posterior portion (Fig. 3E, F).

\section{Differential indices of adult worms}

The ratios of body length (BL) to body width (BW) were 5.15 and 5.19 in 2-week-old and 3-week-old worms. Those of ventral sucker (VS) to oral sucker (OS) were 3.13 and 3.12. The ratios of length (L)/width (W) in the ovary were 0.95 and 0.98 , those in the anterior testis were 1.59 and 1.68 , and in the posterior testis were 1.85 and 2.04. The percentages of forebody length (FBL) to BL were $14.8 \%$ and $12.4 \%$, and those of hindbody length (HBL) to BL were $18.7 \%$ and $18.2 \%$. The percentages of uterine field (UL) to BL were $18.1 \%$ and $20.9 \%$ (Table 2).

\section{DISCUSSION}

In the present study, it was first confirmed that $E$. macrorchis metacercariae are to be infected in Chinese mystery snails, $C$. chinensis malleata, from Xiengkhuang Province, Lao PDR. This echinostome metacercariae were previously found in the same species of snails in Korea [13], in Cipangopaludina sp. in Vientiane Municipality, Lao PDR [12], and in C. japonica in Japan $[21,22]$. And then, Cipangopaludina spp. snails are proved again as the suitable second intermediate hosts of $E$. macrorchis in Japan, Lao PDR and Korea. Besides Cipangopaludina spp., various species of mollusces, i.e., Assiminea, Biomphalaria, Bulinus, Corbicula, Gyraulus, Hippeutis, Lymnaea, Physa, Segmentina and Thiara, and amphibians, i.e., Rana spp. and Hynobius sp., have been reported as the second intermediate hosts of $E$. macrorchis in Japan and Taiwan [11,21-24]. Meanwhile only 2 species of freshwater snails, i.e., Segmentina hemisphaerula and Gyraulus chinensis, were known to be the first intermediate host of $E$. macrorchis in Japan and Taiwan $[11,24]$. As the natural definitive hosts of E. macrorchis, some species of rodents, i.e., Apodemus spp., Microtus montebelli, Mogera spp. and Rattus spp., a species of bird, Capella gallinago gallinago, and humans have been reported in the literatures [3-10]. Accordingly, studies on the life history of this echinostome species including on the first intermediate and natural definitive hosts should be per- formed in the near future in Lao PDR as well as in Korea.

In the present study, E. macrorchis metacercariae were $125 \times 123$ in average size. They were almost same sizes with those from Taiwan $(122 \times 118)$ and Vientiane Municipality, Lao PDR $(121 \times 120)[11,12]$. However they were more or less larger than those from Korea $(110 \times 108)$ [13]. The metacercariae from 3 countries, i.e., Taiwan, Lao PDR and Korea, were nearly round, whereas those from Japan were elliptical in shape $[11-13,25]$. Whether these differences are originated from the geographical and/or host variation or are from the taxonomic significance should be traced through further comparative morphological and molecular genetic studies with each isolates from 4 countries.

Adult worms recovered in this study could be assigned to the subfamily Echinostomatinae, because they have more or less elongated body and dorsally uninterrupted row of collar spines. Additionally, their head collar is well-developed with a double row of spines and their uterine tubules are long with numerous eggs, so they are to be diagnosed as a member of Echinostoma. More than 11 Echinostoma species, i.e., E. academica, E. aegyptiaca, E. attenuatum, E. australasianum, E. azerbaidjanicum, E. coromandum, E. coronale, E. dietzi, E. gotoi, E. macrorchis, and E. phasianina, are known to have 43-45 collar spines [26-31]. And then we are able to assign our specimens to E. macrorchis by the following reasons. The body length of our specimens do not exceed $6.5 \mathrm{~mm}$ like in E. academica, $E$. aegyptiaca, E. attenuatum, E. macrorchis, and E. phasianina, whereas other species, i.e., E. australasianum, E. azerbaidjanicum, E. coromandum, E. coronale, E. dietzi, and E. gotoi, exceed $13.0 \mathrm{~mm}$. E. academica has a very prominent and large head collar compared with that of E. aegyptiaca and E. macrorchis [28]. Our specimens has a moderately developed head collar like that of E. aegyptiaca and E. macrorchis [11,20,32]. Morphologies of the testes, i.e., large, elliptical, slight indentations near the middle, more or less irregular margins, and a pointed posterior end of the posterior testis, in our specimens are compatible with E. macrorchis [3,11], but not those of E. aegyptiaca, which has smooth surface and rounded posterior end of the posterior testis $[32,33]$. The testes of remain 2 species, i.e., $E$. attenuatum and E. phasianina, are small, or slender and elongated, which apparently differ from our specimens.

Sohn et al. [13] proposed the differential indices for E. macrorchis based on the data from 40 worms, which were recovered from experimental rats at 15, 20, 25, and 30 days after infection in Korea (Table 2). When we compared them with 
those from our specimens, the worm body (the ratio of $\mathrm{BL} /$ BW: 5.30-5.76) is slightly slender than our specimens (5.15 and 5.19); the ratios of VS/OS, $\mathrm{L} / \mathrm{W}$ in the ovary and $\mathrm{L} / \mathrm{W}$ in 2 testes are nearly equal with those of our study; the proportions (\%) of FBL/BL and HBL/BL are not so different with those of this study; the proportion of UL/BL (28.2\%) is much higher than those of our study (18.1\% and $20.9 \%)$; the number of collar spines, 45 , in the head collar is more than in our specimens, 43 including 5 end group ones on each side. On the other hand, the size of eggs was more or less small in our specimens (88-96 $\times 55-60)$ than in Sohn et al. [13] (93$105 \times 53-64)$, but nearly equal with that in Sohn et al. [12] (88-98×55-61).

Through the present study, the presence of E. macrorchis was reconfirmed in Lao PDR, and also confirmed that the Chinese mystery snail, C. chinensis malleata, acts as the second intermediate host of this echinostome species in Xiengkhuang Province, Lao PDR like in Korea. However, some morphological differences such as the number of collar spines and differential indices of organs, should be clarified in near future for the taxonomic validity of $E$. macrorchis.

\section{ACKNOWLEDGMENTS}

We thank Jung-A Kim and Hee-Joo Kim (Department of Parasitology and Tropical Medicine, Gyeongsang National University College of Medicine, Jinju, Korea), for their help in the examination of snails, and the recovery of adult worms from experimental animals.

\section{CONFLICT OF INTEREST}

The authors have no conflicts of interest concerning the work reported in this paper.

\section{REFERENCES}

1. Chai JY. Echinostomes in humans. In Fried B, Toledo R, eds, The Biology of Echinostomes: from the Molecule to the Community. New York, USA. Springer. 2009, pp 147-183.

2. Huffman JE, Fried B. Echinostoma and echinostomiasis. Adv Parasitol 1990; 29: 215-269.

3. Ando R, Ozaki Y. On four new species of trematodes of the family Echinostomatidae. Dobutsugaku Zasshi 1923; 35: 108-119 (in Japanese).

4. Majima M. Echinostoma macrorchis found in a man. Tokyo Iji
Shinshi 1927; 2552: 2260-2263.

5. Shibue H. Studies on the trematodes of birds in Kyushu. Kurume Igakkai Zasshi 1954; 17: 178-183 (in Japanese).

6. Okabe N, Okabe K. On a human case infected with three species of trematodes. Nippon Iji Shimpo 1972; 2531: 46-48 (in Japanese).

7. Yokohata Y, Hisashi ABE, Jiang YP, Kamiya M. Gastrointestinal helminth fauna of Japanese moles, Mogera spp. Jpn J Vet Res 1989; 37: 1-13.

8. Ito M, Itagaki T. Survey on wild rodents for endoparasites in Iwate Prefecture, Japan. J Vet Med Sci 2003; 65: 1151-1153.

9. Fischthal JH, Kuntz RE. Some digenetic trematodes of mammals from Taiwan. Proceed Helminthol Soc Washington 1975; 42: 149-157.

10. Fischthal JH, Kuntz RE. Additional records of digenetic trematodes of mammals from Taiwan. Proceed Helminthol Soc Washington 1981; 48: 71-79.

11. Lo CT. Echinostoma macrorchis: life history, population dynamics of intramoluscan stages, and the first and second intermediate hosts. J Parasitol 1995; 81: 569-576.

12. Sohn WM, Chai JY, Na BK, Yong TS, Eom KS, Park H, Min DY, Rim HJ. Echinostoma macrorchis in Lao PDR: Metacercariae in Cipangopaludina snails and adults from experimentally infected animals. Korean J Parasitol 2013; 51: 191-196.

13. Sohn WM, Na BK. Echinostoma macrorchis (Digenea: Echinostomatidae): metacercariae in Cipangopaludina chinensis malleata snails and adults from experimental rats in Korea. Korean J Parasitol 2017; 55: 541-548.

14. Chai JY, Hongvanthong B. A small-scale survey of intestinal helminthic infections among the residents near Pakse, Laos. Korean J Parasitol 1998; 36: 55-58.

15. Chai JY, Park JH, Han ET, Guk SM, Shin EH, Lin A, Kim JL, Sohn WM, Yong TS, Eom KS, Min DY, Hwang EH, Phommasack B, Insisiengmay B, Rim HJ. Mixed infections with Opisthorchis viverrini and intestinal flukes in residents of Vientiane Municipality and Saravane Province in Laos. J Helminthol 2005; 79: 1-8.

16. Chai JY, Han ET, Guk SM, Shin EH, Sohn WM, Yong TS, Eom KS, Lee KH, Jeong HG, Ryang YS, Hoang EH, Phammasack B, Insisiengmay B, Lee SH, Rim HJ. High prevalence of liver and intestinal fluke infections among residents of Savannakhet Province in Laos. Korean J Parasitol 2007; 45: 213-218.

17. Chai JY, Han ET, Shin EH, Sohn WM, Yong TS, Eom KS, Min DY, Um JY, Park MS, Hoang EH, Phammasack B, Insisiengmay B, Lee SH, Rim HJ. High prevalence of Haplorchis taichui, Prosthodendrium molenkampi, and other helminth infections among people in Khammoune Province, Lao PDR. Korean J Parasitol 2009; 47: 243-247.

18. Chai JY, Yong TS, Eom KS, Min DY, Shin EH, Banouvong V, Insisiengmay B, Insisiengmay S, Phammasack B, Rim HJ. Prevalence of the intestinal flukes Haplorchis taichui and H. yokogawai in a mountainous area of Phongsaly Province, Lao PDR. Korean J Parasitol 2010; 48: 339-342.

19. Chai JY, Sohn WM, Yong TS, Eom KS, Min DY, Hoang EH, 
Phammasack B, Insisiengmay B, Rim HJ. Echinostome flukes recovered from humans in Khammouane Province, Lao PDR. Korean J Parasitol 2012; 50: 269-272.

20. Chai JY, Chang TH, Jung BK, Shin HJ, Sohn WM, Eom KS, Yong TS, Min DY, Hoang EH, Phammasack B, Insisiengmay B, Rim HJ. Echinochasmus caninus n. comb. (Trematoda: Echinostomatidae) infection in eleven riparian people in Khammouane Province, Lao PDR. Korean J Parasitol 2019; 57: 451-456.

21. Takahashi S. The life cycles of Echinostoma cinetorchis and E. macrorchis, particularly on their first and second intermediate hosts. Fukuoka Ika Daigaku Zasshi 1927; 20: $712-723$ (in Japanese).

22. Kurisu S. Study on trematodes who take Viviparus as their intermediate host. Seiikai Zasshi 1930; 49: 65-73 (in Japanese).

23. Kurokawa T. Studies on trematodes taking Bulinus (Parafossarulus) striatus (Pilsbry) as their intermediate host and on their metacercariae. Tokyo Iji Shinshi 1935; No. 2937: 1795-1800 (in Japanese).

24. Yamashita J. Echinostome. Progr Med Parasitol Japan 1964; 1: 289-313.

25. Komiya Y. Metacercariae in Japan and adjacent territories. Progr Med Parasitol Japan 1965; 2: 1-328.

26. Bashikirova E. Family echinostomatidae dietz, 1909. In Skrjabin KI ed, Trematodes of Animals and Man. Vol. I. Moscow, Russia. Academy of Sciences of the USSR. 1947, pp 246-305 (English translated version).

27. Skrjabin KI, Petrov AM, Bashikirova E. Echinostomes of domestic and wild birds in USSR. In Skrjabin KI ed, Trematodes of Animals and Man, Vol. I. Moscow, Russia. Academy of Sciences of the USSR. 1947, pp 306-407 (English translated version).

28. Skrjabin KI, Bashikirova E. Family Echinostomatidae dietz, 1909. In Skrjabin KI ed, Trematodes of Animals and Man. Vol. XII. Moscow, Russia. Academy of Sciences of the USSR. 1956, pp 53-930.

29. Odening K. Trematoden aus Indischen Vögeln des Berliner Tierparks. Zeitsch Parasitenkd 1962; 21: 381-425.

30. Yamaguti S. 1971. Genus Echinostoma Rud., 1809. In Synopsis of Digenetic Trematodes of Vertebrates (Vol. I \& II). Tokyo, Japan. Keigaku Publishing Co. 1971, pp 529-533.

31. Kanev I, Fried B, Radev V. Collar spine models in the genus Echinostoma (Trematoda: Echinostomatidae). Parasitol Res 2009; 105: 921-927.

32. Khalil M, Abaza MS. A new trematode parasite of the rat, Echinostoma aegyptiaca nov. sp. Rep Notes Publ Hlth Labs Cairo 1924; 6: 187-189.

33. Yamaguti, S. Studies on the helminth fauna of Japan. Part. 27. Trematodes of mammals, II. Japanese J Med Sci 1939; 1: 131151. 